\author{
The Science Progress and Research \\ Official Journal of the Zhende Research Group, \\ Vol 1(1) Jan 2020:44-46
}

\section{Age and AgNor- A Morphometric study}

Manpreet Kaur ${ }^{1}$, Smita Naik ${ }^{2}$, Sachin Jindal $^{3}$

${ }^{1}$ Senior Lecturer, Dept of Oral Pathology, Guru Nanak Dev Dental College And Hospital, Sunam, Punjab, India.

${ }^{2}$ Professor, Dept of Oral Pathology, Pacific Dental College and Hospital, Rajasthan, India.

${ }^{3}$ Reader, Dept of Oral Pathology, Guru Nanak Dev Dental College and Hospital, Sunam, Punjab, India.

Received: 5 Jan 2021 , Revised: 20 Jan 2021 Accepted for Publication: 23 Jan 2021

Abstract:

Aim and objective:- To investigate and correlate total AgNOR area/Total nucleus area (TAA/TNA ) values in buccal epithelial cells of healthy individuals in different age groups.

Material and Methodology:- In present study 50 healthy individuals are included with age ranging 10 to 60 years. These are divided into 5 groups.Group1-10-20year, Group2-2030year, Group3-30-40year, Group4-40-50year, Group5-50-60year. Oral epithelial cells collected with the help of cyto brush from buccal mucosa. Smears were prepared on clean glass slides and fixed with $95 \%$ alcohol. Fixed slides Smears were stained with AgNOR stain. Results: Statistically significant correlations were found between mean TAA/TNA values and age $p<0.001$ for linear and $p<0.0001$ for polynominal regression, and between AgNOR number and age, $\mathrm{p}<0.001$ for linear.

Conclusion: There is a significant correlation between age and AgNOR amount (ribosome biosynthesis rate) in buccal epithelial cells of healthy individuals. AgNORs in buccal epithelial cells may be used for detection of age.

Keywords: AgNoR area, buccal epithelial cells, Age groups, Ribosome biosynthesis rate

\section{INTRODUCTION}

Nuclear organizer region (NOR) are chromosomal segments in which ribosomal RNA is encoded. The NOR's stained by silver are named argyrophilic nuclear organizer regions (AgNORs). It has been consistently shown that AgNOR count represents a valuable parameter of cell kinetics and therefore cell proliferation ${ }^{1}$.

In younger age groups enhanced growth and differentiation occur so more genesite become transcriptionally active and also showing higher no. of NORs while with gradually increase in age, decrease in development processes occur and decrease in transcriptionally active gene leads to decrease in NORs ${ }^{2}$.

The number, size and arrangement of AgNOR have shown a correlation with the indicators of cellular proliferative indicators. Reduction of AgNOR area occurs due to loss of progressive inactivation of ribosomal RNA (rRNA) genes with aging ${ }^{3}$. There are many studies related to the NORs in oral epithelial cells which signify the increase in AgNOR counts in smoker's mucosa, precancerous and cancerous mucosa, indicating changes that could be assessed at cellular level before any structural changes in the mucosa could take place. But very few studies correlating AgNOR area with different age groups in healthy individuals.

Aim and objective -To investigate and correlate total AgNOR area/Total nucleus area (TAA/TNA ) values in buccal epithelial cells of healthy individuals in different age groups.

\section{MATERIALS AND METHOD}

In present study 50 healthy individuals are included with age ranging 10 to 60 years. These are divided into 5 groups.

Group1-10-20year

Group2-20-30year

Group3-30-40year

*Corresponding Author:

Sachin Jindal, Reader,

Guru Nanak Dev Dental College and Hospital, Sunam, Punjab, India.

Email: Jassalmanu50@gmail.com 
Group4-40-50year

Group5-50-60year

Oral epithelial cells collected with the help of cyto brush from buccal mucosa. Smears were prepared on clean glass slides and fixed with 95\% alcohol. Fixed slides Smears were stained with AgNOR stain

\section{Preparation of solution ${ }^{4}$}

Solution A: $50 \%$ Aqueous Silver nitrate solution was prepared by dissolving $5 \mathrm{gms}$ of aqueous silver nitrate in $10 \mathrm{cc}$ of distilled water. It was filtered through 0.22 micron Millipore Filter and placed in dark before it was used to prepare working solution.

Solution B: Gelatin 2 gm\% w/v was prepared by dissolving 2 gms gelatin in $99 \mathrm{ml}$ of distilled water. One $\mathrm{ml}$ pure formic acid was added to above prepared gelatin solution

Working Solution (Ploton et al 1986)

- Finally mixing both the solution

- Solution A: 2 parts and Solution B: 1 part.

- $\quad$ Slides were placed - 45 minutes

- This mixture was kept in dark till light brown colour developed.

- $\quad$ Slides - washed with running water

- Dehydrated and mounted with DPX.

Finally stained slides was evaluated by analyzing the nuclei of 10 cells/ slides under oil immersion lens and area was evaluated with image analysis (Fig 1).

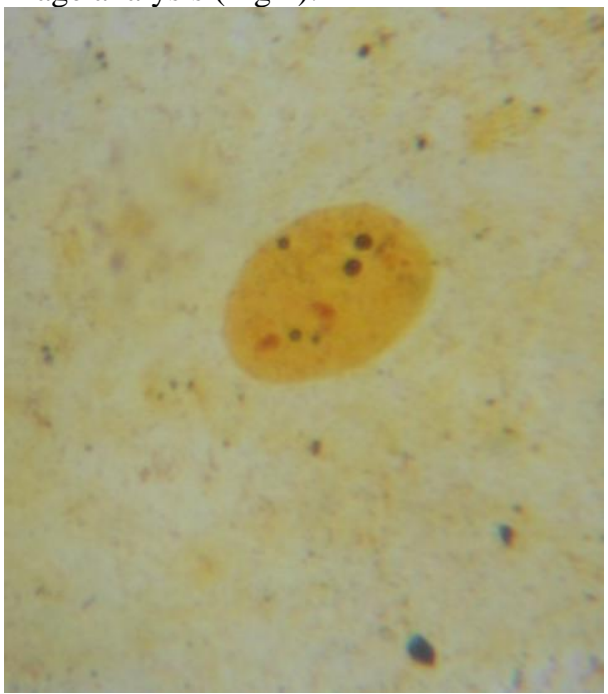

Fig 1 AgNOR staining TAA/TNA area

\section{RESULTS:-}

The mean age of group was $33.02 \pm 23.11$. The demographical features of individuals are given in Table 1. The mean AgNOR number and TAA/TNA were found to be $5.9 \pm 2.011$ and $4.17 \pm 0.893$, respectively. Age groups, evaluated buccal epithelial cells, AgNOR number, TAA/TNA and $p$ value. The data were analyzed for age and both AgNOR number and TAA/TNA using Pearson correlation test. According to this data, a significant correlation was found between age and both AgNOR number and TAA/TNA $(\mathrm{p}<0.001)$. When the individuals were divided into four agegroups, significant differences were found among all age groups for AgNOR number and TAA/TNA ratio $(\mathrm{p}<0.001)$. When the polynominal regression was performed, the correlation between age and both AgNOR number for logarithmic regression and for cubic regression, respectively $(\mathrm{p}<0.0001)$.

Table-1 Comparisons of TAA/TNA with each group

\begin{tabular}{|c|c|c|c|c|}
\hline $\begin{array}{l}\text { No.of } \\
\text { Groups }\end{array}$ & $\begin{array}{l}\text { Mean of } \\
\text { total area of } \\
\text { agnor(TAA) }\end{array}$ & $\begin{array}{l}\text { Mean of } \\
\text { total } \\
\text { nuclear } \\
\text { area(TNA) }\end{array}$ & TAA/TNA & P-Value \\
\hline $\begin{array}{l}\text { Group } \\
-1\end{array}$ & 136.611 & 263.22632 & 0.51899 & \multirow[t]{5}{*}{0.00043} \\
\hline $\begin{array}{l}\text { Group- } \\
2\end{array}$ & 99.83926 & 217.095 & 0.4598 & \\
\hline $\begin{array}{l}\text { Group- } \\
3\end{array}$ & 87.1006 & 299.251 & 0.29106 & \\
\hline $\begin{array}{l}\text { Group- } \\
4\end{array}$ & 35.95162 & 245.941 & 0.1461 & \\
\hline $\begin{array}{l}\text { Group- } \\
5\end{array}$ & 15.7686 & 316.934 & 0.04975 & \\
\hline
\end{tabular}

\section{DISCUSSION}

Nucleolar organizer regions (NOR) also contains a set of acidic, non-histone proteins that bind to silver ions and are selectively visualized by silver methods in routinely processed cyto-histological samples. The NOR stained by silver and the argyrophilic NOR-associated proteins are called "AgNOR" and "AgNOR proteins".

The present study showed variation in the argyrophilic nuclear organizing region (AgNORs) from younger to older age group .

We found different mean of total area of agnor (TAA) andmean of total nucleus area (TNA). We found mean total area of agnor 136.611(Group-1), $\quad$ 99.839.26(Group-2), 87.1006(Group-3), $\quad$ 35.95162(Group-4), 15.786( Group-5) and mean of total nucleus area (TNA).

In younger group( 10-20 year) we found more AgNOR area as compared to the older group(50-60year). 
This showed highly significant results between each age group. Burakselvi et al (2015) also found a significant correlation between age and AgNORs area in buccal epithelial cells of healthy individuals, which supports our study(1).

Many studies have been done on the basis of number of AgNOR but according to Joao et al(2011) to avoid different factors which affect the numeric factors of AgNOR, morphometric analysis should be done to avoid the mistakes produced by union of particles ${ }^{7}$.

\section{CONCLUSION}

AgNORs area has significant effect in the oral epithelial cells .It can be used as a diagnostic tool for diagnosing the normal activity of cells with the age, as well as the proliferating activity of cells which is indicative of precancerous or cancerous changes in oral epithelial cells.

\section{REFERENCES}

1. Selvi B, Demirtas H, Eroz R, Imamoglu N. Reduction of the argyrophilic nucleolar organizing region associated protein synthesis with age in buccal epithelial cells of healthy individuals. Aging clinical and experimental research. 2015;27(2):201-8.

2. Metze K, Lorand-Metze I. Age related decrease of AgNOR activity in acute and chronic lymphocytic leukaemias. Molecular Pathology. 1999;52(1):52.

3. Treré D, Ceccarelli C, Montanaro L, Tosti E, Derenzini M. Nucleolar size and activity are related to $\mathrm{pRb}$ and $\mathrm{p} 53$ status in human breast cancer. Journal of Histochemistry \& Cytochemistry. 2004;52(12):1601-7.

4. Bhatt J, Patel T, Sarvaiya S, Modha D, Gajjar M. Silver stained nucleolar organizer region count (AgNOR count)-very useful tool in breast lesions. Natl J Med Res. 2013;3:2802.

5. Ploton D, Menager M, Jeannesson P, Himber G, Pigeon F, Adnet J. Improvement in the staining and in the visualization of the argyrophilic proteins of the nucleolar organizer region at the optical level. The Histochemical Journal. 1986;18(1):5-14.

6. Thiele MCdM, Bohn JC, Chaiben CL, Grégio AMT, Machado MÂN, de Lima AAS. Nucleolar organizer regions of oral epithelial cells in crack cocaine users. Iranian biomedical journal. 2013;17(2):107.

7. Hanemann JAC, Miyazawa M, Souza MSGdS. Histologic grading and nucleolar organizer regions in oral squamous cell carcinomas. Journal of Applied Oral Science. 2011;19(3):280-5. 